\title{
PHYSICAL AND CHEMICAL STABILITY TEST OF NEEM OIL CREAM (AZADIRACHTA INDICA) USING HIGH-PERFORMANCE LIQUID CHROMATOGRAPHY
}

\author{
FEBRINA AMELIA SAPUTRI ${ }^{*}{ }^{*}$, PATIHUL HUSNI², NORISCA ALIZA PUTRIANA ${ }^{2}$
}

${ }^{1}$ Faculty of Pharmacy, Universitas Indonesia, Depok, Indonesia, ${ }^{2}$ Department of Pharmaceutics and Pharmaceutical Technology, Faculty of Pharmacy, Universitas Padjadjaran, Bandung, Indonesia

Email: febrina.amelia@farmasi.ui.ac.id

Received: 22 Mar 2021, Revised and Accepted: 10 May 2021

ABSTRACT

Objective: This study aims to examine the physical and chemical stability of neem oil cream.

Methods: Physical stability was conducted by storing the cream at room temperature $\left(25 \pm 2{ }^{\circ} \mathrm{C} / 65 \% \mathrm{RH} \pm 5 \% \mathrm{RH}\right)$ and high temperature $\left(40 \pm 2{ }^{\circ} \mathrm{C} / 75 \% \mathrm{RH} \pm 5 \% \mathrm{RH}\right)$ for 3 mo. HPLC method using Dionex with UV detection at $219 \mathrm{~nm}$, Shodex (C-18) HPLC packed column (4.6 mmID x $250 \mathrm{mmL}$ ), acetonitrile: water [30:70] as mobile phase, 10 min isocratic elution with a flow rate of $1.0 \mathrm{ml} / \mathrm{min}$ with volume injection $20 \mu \mathrm{L}$ was validated then was carried out to measure azadirachtin levels in neem oil cream. The chemical stability of azadirachtin in the cream was determined for $90 \mathrm{~d}$ by using this validated method.

Results: The neem oil cream was physically stable. The HPLC method of azadirachtin meets all the validation parameters and can be used to analyze the chemical stability of azadirachtin in neem oil cream. Neem oil cream was stable for $4 \mathrm{w}$ at $25^{\circ} \mathrm{C}$ and for $1 \mathrm{w}$ at $40^{\circ} \mathrm{C}$.

Conclusion: The neem oil cream was either physically or chemically stable for $4 \mathrm{w}$ at $25^{\circ} \mathrm{C}$ and $1 \mathrm{w}$ at $40{ }^{\circ} \mathrm{C}$

Keywords: Azadirachtin, Chemical stability, High-performance liquid chromatography, Neem oil cream, Physical stability

(C) 2021 The Authors. Published by Innovare Academic Sciences Pvt Ltd. This is an open access article under the CC BY license (https://creativecommons.org/licenses/by/4.0/) DOI: https://dx.doi.org/10.22159/ijap.2021v13i4.41539. Journal homepage: https://innovareacademics.in/journals/index.php/ijap

\section{INTRODUCTION}

Neem (Azadirachta indica) is a plant from the family of Meliaceae that has health-promoting properties. It has been widely used throughout the world, especially in India and China in the treatment and prevention of various diseases [1]. Neem oil is obtained from the seeds by using mechanical pressing, solvent extraction or supercritical fluid extraction [2-4]. Azadirachtin found in neem oil has been known as a bioinsecticide that is very good for treating skin infections such as scabies, zits, psoriasis and eczema and controlling ectoparasites such as lice $[5,6]$.

Scabies is a common pruritic skin infection caused by Sarcoptes scabiei mite. The hallmark of scabies is severe itching, which usually gets worse at night [7,8]. Globally, it is estimated to affect more than 200 million people [9]. In Indonesia, in 2011 and 2013 the prevalence of scabies were $6 \%$ and $3.9 \%$. Scabies in Indonesia ranks third out of the 12 most common skin diseases [10].

The managements of scabies used were topical drugs such as $5 \%$ permethrin cream, 5-10\% sulfur presipitatum cream, 10-25\% benzyl benzoate, $10 \%$ crotamiton cream, gamma benzene $1 \%$ chlorine cream (lindane lotion $1 \%$ ) [11]. Preparations on the market have a high selling price so another treatment that can be used is using traditional medicine. One of the potential plants used for the treatment of scabies is neem plants by utilizing the oil [11].

The cream is one of an emulsion semisolid preparation with a water content of more than $20 \%$ and/or less than $50 \%$ of hydrocarbons, waxes, or polyethylene glycols and is intended for external use or topical [12]. Topical preparations in the form of creams are preferred because of their many advantages, including non-invasive delivery, avoiding the first-pass metabolism, and improving patient compliance [13]. Our previous study showed the concentration of neem oil used in cream formulations is $30 \%$ because it is considered to have the best level of effectiveness with the fastest healing time in scabies, which is 9-10 d [14].

The stability of a pharmaceutical preparation needs to be tested to find out how the quality of preparation at a certain time and under the influence of various environmental factors such as temperature, humidity and light [15]. The results of stability testing of preparation can be utilized for shelf life prediction, proper storage condition, and recommended labelling instructions [16].

In this study, the physical and chemical stability of the neem oil cream (Azadirachta indica) were carried out. Published analytical methods are often modified in some cases to find precise conditions of the equipment available in the testing laboratory. Therefore, this modification must be validated to ensure the implementation of appropriate testing from the analytical method. Therefore, method validation was carried out before chemical stability of neem oil cream.

\section{MATERIALS AND METHODS}

\section{Materials}

The ingredients used were neem oil (PT Happy Green), adeps lanae (Brataco), stearic acid (Brataco), acetone (Merck), acetonitrile (Merck), aqua bidestillata (IPHA), aqua destillata (CV Rahmat Sejahtera), glycerin (Brataco), sodium tetraborate (Brataco), triethanolamine (Brataco) and methylparaben (Brataco).

\section{Characterization of neem oil}

Characterization results of neem oil used in this study were conducted in our previous study [17]. Characterization of neem oil was carried out to determine the physicochemical properties of neem oil and to determine purity and prevent counterfeiting, including organoleptic, specific gravity, refractive index, acid value, iodine value, peroxide value, and saponification value [17-19].

\section{Neem oil cream formulation}

Melted out mass 1 contained adeps lanae and stearic acid using a water bath at $70{ }^{\circ} \mathrm{C}$. Glycerin, sodium tetraborate, triethanolamine and water all mixed uniformly and heated using a water bath at 70 ${ }^{\circ} \mathrm{C}$ as mass 2 . Nipagin as a preservative was heated up with water and add to mass 2. Mass 1 and 2 were mixed and stirred using a mechanical stirrer until became a solid form cream. Neem oil was added to the cream base and mixed uniformly [17]. 


\section{Physical stability test}

Physical stability testing was carried out on cream preparations at room temperature $\left(25 \pm 2 \quad{ }^{\circ} \mathrm{C} / 65 \quad \% \mathrm{RH} \pm 5 \quad \% \mathrm{RH}\right)$ and high temperature $\left(40 \pm 2{ }^{\circ} \mathrm{C} / 75 \% \mathrm{RH} \pm 5 \% \mathrm{RH}\right)$ for $3 \mathrm{mo}$. The test was carried out in triplicate at each storage temperature [17].

\section{Organoleptic test}

Organoleptic observation was carried out by looking visually and observing changes that occur in the preparation. The neem oil cream formula was tested for stability by taking into account the consistency, colour, and smell of the cream $[17,20]$.

\section{Homogeneity test}

Homogeneity test of cream preparations was performed by applying as much as $0.1 \mathrm{~g}$ dosage cream on the glass object, then levelled and observed, the cream should show homogeneous composition and dispersed evenly in the preparation $[17,20]$.

\section{Cream pH test}

The cream preparation was diluted with aqua destillata first with a ratio of $1: 10$, then the $\mathrm{pH}$ meter was calibrated using a buffer solution $\mathrm{pH} 7$ and $\mathrm{pH}$ 4. The $\mathrm{pH}$ meter electrode was dipped in the sample solution examined. Note the $\mathrm{pH}$ value that appears on the screen. $\mathrm{pH}$ measurements were carried out at room temperature $\left(25 \pm 2{ }^{\circ} \mathrm{C}\right)[17,20]$.

\section{Cream type test}

The cream was put into the vial, then diluted with water. If the cream can be diluted, the cream type is type o/w [17].

\section{Viscosity test}

Viscosity measurements were carried out using a Brookfield viscometer at a speed of $50 \mathrm{rpm}$. Viscosity measurement was done by placing the sample in a viscometer, then the appropriate spindle (spindle no. 5) was inserted into the preparation until it sets [17].

\section{Centrifugation test}

Centrifugation was carried out at $25^{\circ} \mathrm{C}$ and a speed of $3750 \mathrm{rpm}$ for $5 \mathrm{~h}$ by entering 3 grams of the sample in the centrifugation tube. The sample was then observed for its separation [21].

\section{Cycling test}

The cream was stored at $4{ }^{\circ} \mathrm{C}$ for $24 \mathrm{~h}$ then transferred to $40{ }^{\circ} \mathrm{C}$ for $24 \mathrm{~h}$. The test was carried out in 6 cycles and then observed the organoleptic properties [22].

\section{Method validation}

\section{Analytical method optimization}

The HPLC analysis was performed using Dionex HPLC with a UV detector. Shodex (C-18) HPLC packed column (4.6 mmID x 250 $\mathrm{mmL}$ ) was used for the chromatographic separations. The mobile phase consisted of acetonitrile: water [30:70]. The separation was performed using isocratic elution (10 min) with a flow rate of 1.0 $\mathrm{ml} / \mathrm{min}$. The injection volume was $20 \mu \mathrm{L}$, and UV detection at 219 nm.

\section{System suitability test}

The test was performed by injecting $10 \mu \mathrm{g} / \mathrm{ml}$ azadirachtin solution at six replication. The chromatograms of the resulting solutions were recorded and then calculate the peak area, retention time, theoretical plate, tailing factor, and retention factors [23].

\section{Linearity}

ICH recommends that for the establishment of linearity a minimum of 5 concentrations normally used. Linearity was studied by preparing solutions in $2,4,8,16$, and $32 \mu \mathrm{g} / \mathrm{ml}$. Linearity was determined based on the correlation coefficient between concentration and Area under Curve (AUC) [23].

\section{Limit of detection (LOD) and limit of quantification (LOQ)}

LOD and LOQ were determined based on the signal-to-noise approach. This approach was performed by comparing measured signals from samples with a known low concentration of analyte with those of blank samples and by establishing the minimum concentration at which the analyte can be reliably quantified. A typical signal-to-noise ratio is 3:1 for LOD and 10:1 for LOQ [23].

\section{Accuracy}

The accuracy of an analytical method is the closeness of test results obtained by the method to the true value. The test was performed by standard addition method at $80 \%(6 \mu \mathrm{g} / \mathrm{ml}), 100 \%(7.5 \mu \mathrm{g} / \mathrm{ml})$, $120 \%(9 \mu \mathrm{g} / \mathrm{ml})$ of standard concentration and $8 \mu \mathrm{g} / \mathrm{ml}$ of sample concentration. Standard solution was added to analyzed sample and injected to the HPLC system. The recovery study was performed three times at each level [23].

\section{Precision}

The precision of an analytical method is the degree of agreement among individual results when the method is applied repeatedly to multiple readings of a homogeneous sample. It is expressed as $\%$ RSD of series of measurements. The test was performed by standard addition method at $80 \%(6 \mu \mathrm{g} / \mathrm{ml}), 100 \%(7.5 \mu \mathrm{g} / \mathrm{ml})$, $120 \%(9 \mu \mathrm{g} / \mathrm{ml})$ of standard concentration and $8 \mu \mathrm{g} / \mathrm{ml}$ of sample concentration. The standard solution was added to the analyzed sample and injected into the HPLC system. The \%RSD study was performed three times at each level [23].

\section{Specificity}

Specificity was measured as the ability of the proposed method to obtain well-separated peak for the analyte without any interference from other constituents of the plant. Specificity was performed by injecting sample solution, standard solution, spike solution, and blank then the peak area was recorded. The area was very close to the standard indicates no interference from the other constituents of the plant [23].

Table 1: Formula of vanishing and neem oil cream

\begin{tabular}{lll}
\hline Formula & Material & Formula (\%w/w) \\
\hline Vanishing cream & Adeps lanae & 1 \\
& Stearic acid & 14.2 \\
& Glycerin & 10 \\
& Sodium tetraborate & 0.25 \\
& Triethanolamine & 1 \\
Neem oil cream & Aqua destillata & 75 \\
& Methyl paraben & 0.1 \\
& Neem oil & 30 \\
& Vanishing cream & Ad 100 \\
\hline
\end{tabular}

\section{Robustness}

It is a measure of its capacity to remain unaffected by small but deliberated changes in method parameters and provides an indication of its reliability in normal usage [23]. The parameter for HPLC method includes the variation of mobile phase composition from normal condition acetonitrile: water [30:70] into [28:72] and [32:68]. 


\section{Chemical stability test}

Chemical stability testing was carried out on cream preparations at room temperature $\left(25 \pm 2{ }^{\circ} \mathrm{C} / 65 \% \mathrm{RH} \pm 5 \% \mathrm{RH}\right)$ and high temperature $(40 \pm 2$ ${ }^{\circ} \mathrm{C} / 75 \% \mathrm{RH} \pm 5 \% \mathrm{RH}$ ) for $3 \mathrm{mo}$. The test was carried out in triplicate at each storage temperature. One gram of cream neem oil was dissolved in acetone to $10 \mathrm{ml}$. Samples were centrifuged at $3000 \mathrm{rpm}$ for $10 \mathrm{~min}$. The sample was then diluted $60 \mathrm{x}$ until a diluted azadirachtin sample solution was obtained. Then the content was determined [16].

\section{RESULTS AND DISCUSSION}

\section{Characterization of neem oil}

According to our previous study, all of the physicochemical properties of neem oil met the specification [17].

\section{Neem oil cream formulation}

The neem oil cream preparation formula used in this study used a cream base in the form of vanishing cream. The selected formula was further modified by adding the concentration of neem oil by $30 \%$ (table 1 ). This concentration was chosen because it has the best level of effectiveness with the fastest healing time in scabies, which is 9-10 d [14].

\section{Physical stability test}

The organoleptic test results at room temperature $25^{\circ} \mathrm{C}$ showed that the cream base formula and four formulas containing neem oil were stable semuanya homogeneous cream for $90 \mathrm{~d}$ of storage. But in terms of colour and odour changes where the colour changes in the preparation become pale yellow and also the change in smell become not too sharp since the observation on the 30th day. The change in colour and odour in the cream indicated a slight difference in the stability of the ingredients or preparations during storage carried out from the beginning of the preparation.

On storage of cream preparations for $90 \mathrm{~d}$ at high temperatures, $40^{\circ} \mathrm{C}$ can be seen changes in the stability of the preparation organoleptically. The results of observations on cream preparations at a storage temperature of $40{ }^{\circ} \mathrm{C}$ showed homogeneous cream. (table 2). This was concluded that the homogeneity of cream could be said to be stable. Likewise for changes in both smell and colour of cream did not experience significant changes so that it showed no difference in the stability of the ingredients/preparations during storage made from the beginning of the preparation.

Table 2: Organoleptic and homogeneity

\begin{tabular}{llll}
\hline Temperature & Observation (day-) & Colour & Homogeneity \\
\hline $25^{\circ} \mathrm{C}$ & 0 & Yellow & Homogeneous cream \\
& 7 & Hellow & Homogeneous cream \\
& 14 & Yellow & Homogeneous cream \\
& 21 & Yellow & Homogeneous cream \\
& 30 & Pale yellow & Homogeneous cream \\
& 60 & Pale yellow & Homogeneous cream \\
$40{ }^{\circ} \mathrm{C}$ & 90 & Pale yellow & Homogeneous cream \\
& 0 & Yellow & Homogeneous cream \\
& 7 & Yellow & Homogeneous cream \\
& 14 & Yellow & Homogeneous cream \\
& 21 & Yellow & Homogeneous cream \\
& 30 & Yellow & Hellow
\end{tabular}

Note: $\mathrm{n}=3$

Table 3: Physical stability

\begin{tabular}{|c|c|c|c|c|}
\hline Temperature & Observation (day-) & $\mathrm{pH} \pm \mathrm{SD}^{*}$ & Viscosity (cPs) \pm SD* & Centrifugation \\
\hline \multirow[t]{7}{*}{$25^{\circ} \mathrm{C}$} & 0 & $8.18 \pm 0.02$ & $1061.33 \pm 16.17$ & Stable \\
\hline & 7 & $8.17 \pm 0.02$ & $1040.00 \pm 16.00$ & Stable \\
\hline & 14 & $8.18 \pm 0.02$ & $1495.33 \pm 29.95$ & Stable \\
\hline & 21 & $8.23 \pm 0.02$ & $1597.33 \pm 74.33$ & Stable \\
\hline & 30 & $8.12 \pm 0.03$ & $1565.33 \pm 113.80$ & Stable \\
\hline & 60 & $8.13 \pm 0.03$ & $1696.00 \pm 42.33$ & Unstable \\
\hline & 90 & $8.08 \pm 0.03$ & $890.67 \pm 16.65$ & Unstable \\
\hline \multirow[t]{7}{*}{$40^{\circ} \mathrm{C}$} & 0 & $8.19 \pm 0.02$ & $1101,33 \pm 20,13$ & Stable \\
\hline & 7 & $8.23 \pm 0.04$ & $4720.00 \pm 28.84$ & Stable \\
\hline & 14 & $8.19 \pm 0.03$ & $5944.67 \pm 284.57$ & Stable \\
\hline & 21 & $8.15 \pm 0.02$ & $5701.33 \pm 144.07$ & Stable \\
\hline & 30 & $8.12 \pm 0.03$ & $5760.00 \pm 69.74$ & Stable \\
\hline & 60 & $7.97 \pm 0.02$ & $5800.00 \pm 123,158$ & Unstable \\
\hline & 90 & $7.93 \pm 0.02$ & $5293.33 \pm 212.01$ & Unstable \\
\hline
\end{tabular}

Note: Data represented as mean \pm SD $(n=3), * S D$ : Standard Deviation

As drug preparations are given through the skin, neem oil creams must have a $\mathrm{pH}$ range that is adjusted to the topical $\mathrm{pH}$ range with a broad range from $\mathrm{pH} 4.0$ to 7.0 [24]. The results of $\mathrm{pH}$ measurements of the formula from neem oil cream preparations for $90 \mathrm{~d}$ of storage period at $25^{\circ} \mathrm{C}$ and $40{ }^{\circ} \mathrm{C}$ were around 8 (table 3 ) but it could be well tolerated by skin surface (SC) due to a fairly high buffer capacity of SC [25].
Determination of cream type was carried out on in two storage conditions, namely at a temperature of $25{ }^{\circ} \mathrm{C}$ and a temperature of $40{ }^{\circ} \mathrm{C}$ using the phase dilution method. The results of the cream type determination showed that the cream at two storage conditions were at a temperature of $25{ }^{\circ} \mathrm{C}$ and a temperature of $40{ }^{\circ} \mathrm{C}$ until the storage time for $90 \mathrm{~d}$ had the type of oil cream in water $(\mathrm{o} / \mathrm{w})$. 
Viscosity testing was carried out at two storage temperatures and carried out for $90 \mathrm{~d}$ of storage. The desired viscosity of the cream preparation in the criteria required by SNI 16-4399-1996 is between 2000-50,000 cPs. The observation of cream viscosity for $90 \mathrm{~d}$ of storage experienced a change in viscosity caused by the influence of the oil in the form of oily liquid (table 3). Another thing that can affect changes in the value of viscosity is the interaction between components in the cream with the influence of mechanical pressure from the tools used during testing. In addition, the environmental condition of the cream might be affected the viscosity.

Centrifugation test is one indicator of semisolid physical stability. Stokes' Law shows that the formation of cream is a function of gravity and the increase in gravity can accelerate the separation of phases. The cream sample was centrifuged at a speed of $3750 \mathrm{rpm}$ for $5 \mathrm{~h}$ equivalent to the effect of gravity for one year [26]. The test results showed that phase separation occurs in creams stored at 25 ${ }^{\circ} \mathrm{C}$ and at $40{ }^{\circ} \mathrm{C}$ on day 60 (table 3 ). The separation that occurs in the form of creaming where the formation of layers with different concentrations in the emulsion due to density difference in the dispersed and continuous phases, the droplets experience a gravitational force and a buoyancy force. Therefore, particles that have a lower density rise to the surface [27].

Cycling test was carried out to determine the physical stability of the cream preparations. In addition, testing is also done on the product to determine the stability of the emulsion in the cream. When the cream was stored at $4{ }^{\circ} \mathrm{C}$ the thickness of the cream increases. This is due to the oil phase which tends to freeze at low temperatures. When the cream was stored at $40{ }^{\circ} \mathrm{C}$ it did not show any physical changes such as precipitation, phase separation or clump formation which showing stable preparation at high temperatures. The cream showed stable results as indicated by the absence of changes in organoleptic properties including colour, odour and shape as well as a homogeneous cream characterized by no phase separation.

\section{Method validation}

Azadirachtin showed maximum wavelengths at $219 \mathrm{~nm}$. Absorptivity values found in neem oil were determined by three concentrations $5.5 \times 10^{-6} \mathrm{M}, 11 \times 10^{-6} \mathrm{M}$, and $22 \times 10^{-6} \mathrm{M}$. The average value of absorptivity was found to be $492.153 \mathrm{M}^{-1} \mathrm{~cm}^{-1}$. With this result, azadirachtin can be analyzed using spectrophotometer UV.

The optimization was conducted to find the best condition to analyze the azadirachtin in the cream. Several things have to be concerned to find the best condition, such as the type of column, detector, mobile phase, type of elution, flow rate, and volume of injection. The test was run using C18 column, at wavelength $219 \mathrm{~nm}$, the mobile phase was the combination of acetonitrile: water [30:70], the elution was isocratic with flow rate at $1 \mathrm{ml} / \mathrm{min}$, and the injection volume was 20 $\mu \mathrm{L}$. The chromatogram of the method results the specific separation of azadirachtin from the other components (fig. 1).

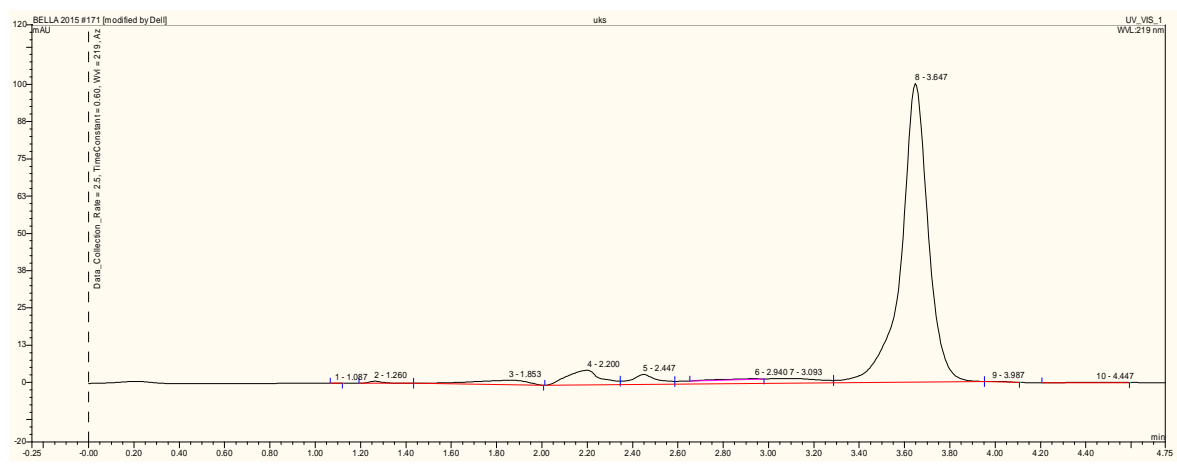

Fig. 1: System suitability testing chromatogram

The system suitability test was performed to see if the system of HPLC was fulfill the acceptance criteria of the analytical method, and to determine the suitability of chromatographic system for analysis. The parameters assessed were HETP, plate number, tailing factor, capacity factor, and selectivity [23]. The result of the system suitability test showed that all the parameters was fulfill the acceptance criteria, thus the system can be used to analyze the azadirachtin (table 4).

Table 4: System suitability

\begin{tabular}{llll}
\hline Parameters & Acceptance criteria & Result \pm SD* & Suitable/unsuitable \\
\hline HETP & Small & $0.04 \pm 0.00$ & Suitable \\
Plate Number (N) & $>2500$ & $5605 \pm 85.68$ & Suitable \\
Tailing Factor (Tf) & 1 & $0.97 \pm 0.01$ & Suitable \\
Capacity Factor (k') & $2<\mathrm{k}^{\prime}<10$ & $2.35 \pm 0.02$ & Suitable \\
Selectivity & $>1$ & $1.23 \pm 0.02$ & Suitable \\
\hline
\end{tabular}

Note: Data represented as mean $\pm S D(n=3),{ }^{*} S D$ : Standard Deviation

The determination of azadirachtin in the creams was classified to be category 1 . All of the validation parameters need to be done except the limit of detection (LOD) and limit of quantification (LOQ), but LOD and LOQ were still determined in this test to see the sensitivity of the method. According to ICH guidelines, $\mathrm{R}^{2}$ value for linearity that fulfills the acceptance criteria is $>0.99$ [23]. The result showed that $\mathrm{R}^{2}$ value was 0.9959 which means there was a strong correlation between concentration and peak area and showed a proportional curve. Calibration curve of azadirachtin shown in fig. 2.
Limit of detection (LOD) is the lowest amount of an analyte that can be detected, while the limit of quantification (LOQ) is the lowest amount of an analyte in a sample that can be quantitatively determined with suitable precision and accuracy. LOD and LOQ were determined based on the signal to ratio method. By using this method, the height of the analyte was compared with the height of a noise. According to ICH guidelines, the ratio between analyte and noise has to be 10:1 for LOQ, and 3:1 for LOD [23]. The LOD was 0.3 $\mu \mathrm{g} / \mathrm{ml}$ and LOQ was $1.1 \mu \mathrm{g} / \mathrm{ml}$. Signal to noise ratio chromatogram shown in fig. 3. 


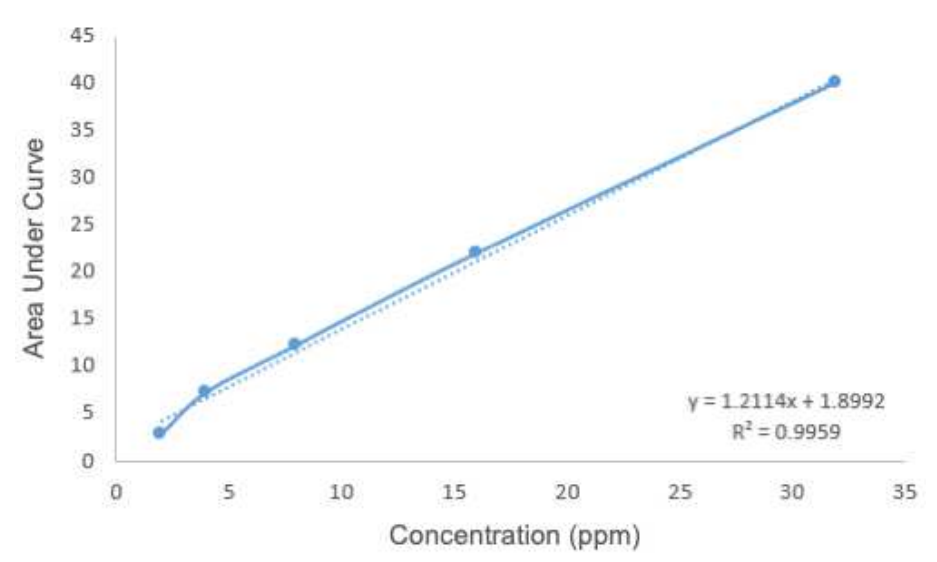

Fig. 2: Calibration curve of azadirachtin

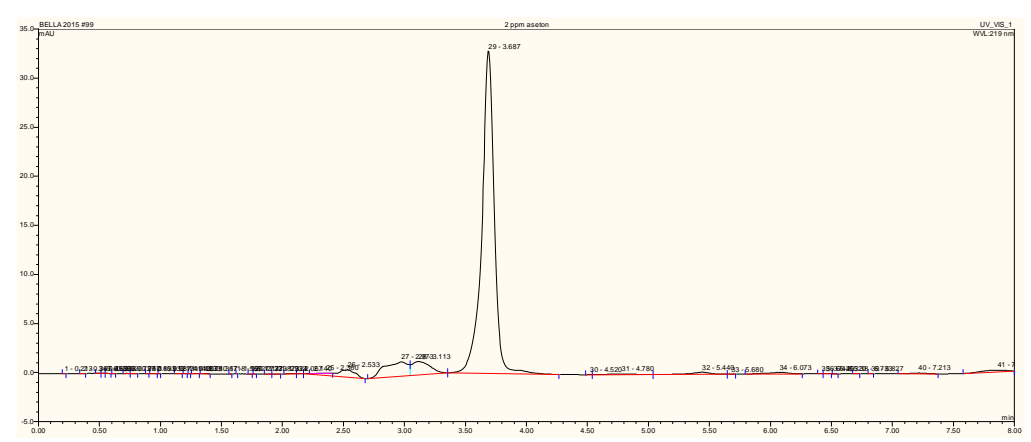

Fig. 3: Signal to noise ratio chromatogram

Accuracy of an analytical method is the closeness of the test results obtained by the method to the true value. The test was conducted by using three concentration with triplicate each concentration. The test was performed by standard addition method at $80 \%(6 \mu \mathrm{g} / \mathrm{ml})$, $100 \%(7.5 \mu \mathrm{g} / \mathrm{ml}), 120 \%(9 \mu \mathrm{g} / \mathrm{ml})$ of standard concentration and
$8 \mu \mathrm{g} / \mathrm{ml}$ of sample concentration [28]. Addition method has it advantages to minimalize the interference from the other components. Results from recovery studies were within acceptable criteria 97.7-100.3\% indicating the accuracy of the method was good [23]. The accuracy data of azadirachtin shown in table 5.

Table 5: Accuracy and precision of azadirachtin by the proposed HPLC method

\begin{tabular}{lll}
\hline Level (\%) & \%Recovery \pm SD* & \%Relative standard deviation \\
\hline 80 & $97.7 \% \pm 1.930$ & $1.528 \%$ \\
100 & $100.3 \% \pm 1.679$ & $1.674 \%$ \\
120 & $99.46 \% \pm 0.260$ & $0.261 \%$ \\
\hline
\end{tabular}

Note: Data represented as mean \pm SD $(n=3), * S D$ : Standard Deviation

Precision of azadirachtin was carried out by estimating the corresponding responses three times on the same day and expresses as \%RSD. Same as accuracy, the test was performed by standard addition method at $80 \%(6 \mu \mathrm{g} / \mathrm{ml}), 100 \%(7.5 \mu \mathrm{g} / \mathrm{ml}), 120 \%$ (9 $\mu \mathrm{g} / \mathrm{ml})$ of standard concentration and $8 \mu \mathrm{g} / \mathrm{ml}$ of sample concentration [28]. The results for precision was $0.26-1.5 \%$ which suggested a great precision of method [23]. The precision data of azadirachtin shown in table 5 .

Specificity test was carried out to determine whether the method specifically separates the analyte from other interference [23]. This test is also intended so that the method can distinguish the analyte from sample matrixes. This test was performed by comparing the chromatogram of standard, sample, blank, and spike solution. From the chromatogram, we can know that at the peak of analyte was specific only peak of analyte that shown, and there is no interference from the other components. So, it can be declared that the system can specifically detecting azadirachtin. The overlay chromatogram shown in fig. 4 .

The robustness measure its capacity to remain unaffected by the small but deliberate change in method parameters and provides an indication of its reliability in normal usage. A method that claimed has a good robustness, if only the method was change by a little condition it still has the same value or change a little bit from the normal value. Robustness was expressed with \%RSD. This test was conducted by the change of the combination of mobile phase $\pm 2 \%$ from the normal condition [23]. The \%RSD from the test was 1.151 $\%$, which means there is small deliberate changes in the developed HPLC method indicated the robustness of method. The robustness data of azadirachtin shown in table 6.

Table 6: Robustness of azadirachtin

\begin{tabular}{lll}
\hline $\begin{array}{l}\text { Mobile phase } \\
\text { composition }\end{array}$ & RT $^{* *} \pm$ SD $^{*}$ & $\begin{array}{l}\text { \%Relative standard } \\
\text { deviation }\end{array}$ \\
\hline $28: 72$ & $3.713 \pm 0.006$ & 1.151 \\
$30: 70$ & $3.655 \pm 0.008$ & \\
$32: 68$ & $3.618 \pm 0.005$ & \\
\hline
\end{tabular}

Note: Data represented as mean \pm SD $(n=3),{ }^{*}$ SD: Standard Deviation, **RT: Retention Time 


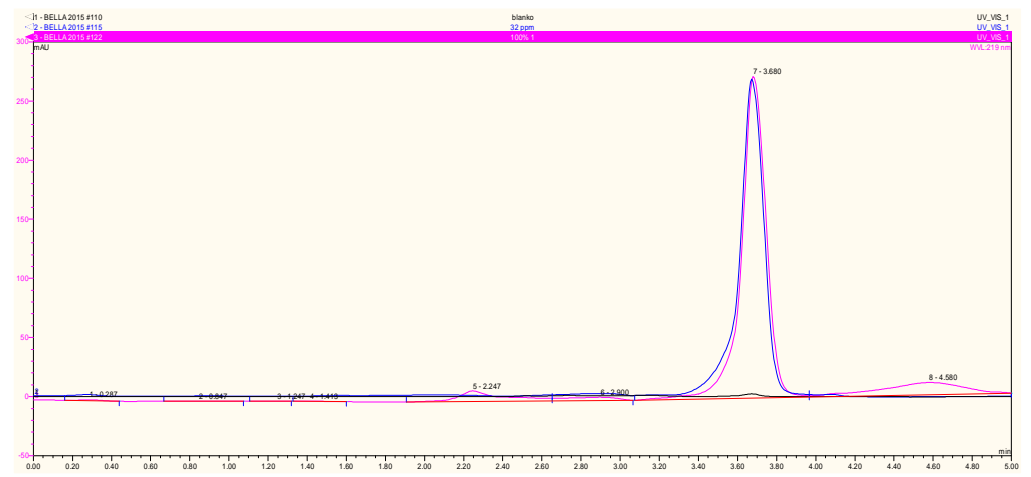

Fig. 4: Specificity chromatogram

\section{Chemical stability test}

Cream samples were extracted using acetone pro analysis. The choice of solvent is based on the solubility of azadirachtin which is easily soluble in acetone [29].

Stability testing for 3 mo showed a continuous decrease in azadirachtin levels. Azadirachtin levels in the pulp cream at week 7 were stored at $25{ }^{\circ} \mathrm{C}$ at $52.9 \%$ and at $40{ }^{\circ} \mathrm{C}$ at $45.49 \%$. In the 8th to 12 th week, azadirachtin levels cannot be calculated because azadirachtin has been decomposed. This is evidenced by the appearance of 2 peaks that are not completely separated so that the AUC value cannot be calculated. The decrease in azadirachtin levels can be seen in fig. 5 .

Pharmaceutical products are said to be stable and can still be consumed if the preparation contains at least $90 \%$ active ingredients. This shows that the permissible maximum decomposition limit is $10 \%[30,31]$. From fig. 5 it can be seen that neem cream was chemically stable for $4 \mathrm{w}$ at a storage temperature of $25^{\circ} \mathrm{C}$ and for $1 \mathrm{w}$ at a storage temperature of $40^{\circ} \mathrm{C}$.

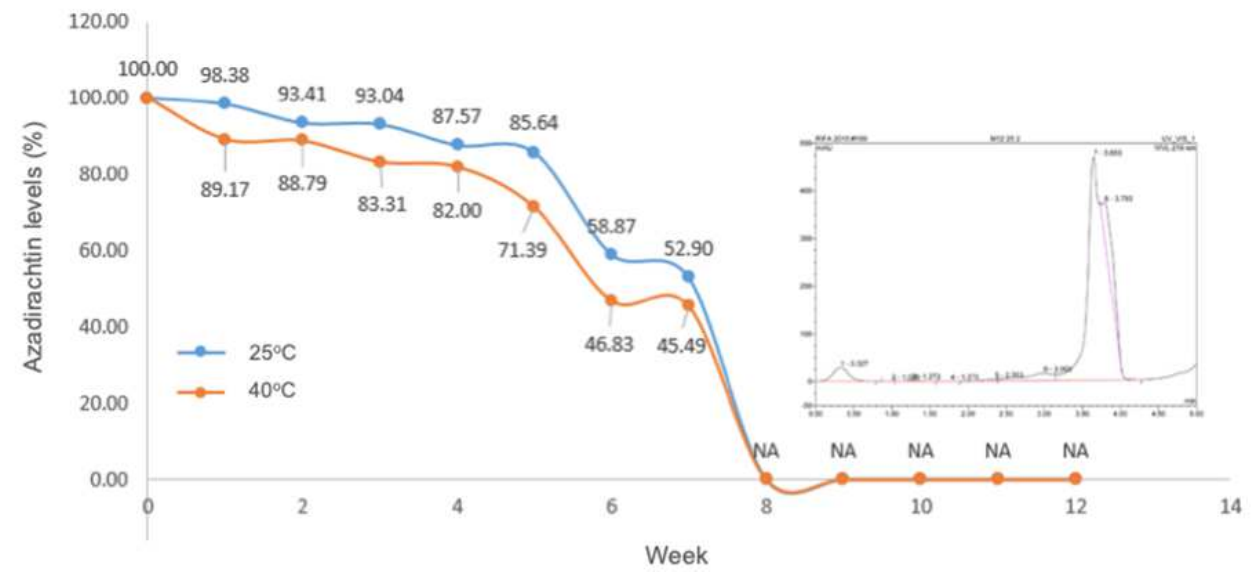

Fig. 5: Azadirachtin levels in neem oil cream $(n=3)$

\section{CONCLUSION}

A physically stable neem oil cream formula has been successfully developed. Likewise, the analytical method of azadirachtin in cream has been successfully developed and meets the validation parameters. This method was used to analyze the chemical stability of azadirachtin in neem oil cream. Neem oil cream was stable for $4 \mathrm{w}$ at $25^{\circ} \mathrm{C}$ and for $1 \mathrm{w}$ at $40{ }^{\circ} \mathrm{C}$.

\section{ACKNOWLEDGEMENT}

The authors are grateful to the Rector of Universitas Padjadjaran for funding this study. The authors are also thankful to Faculty of Pharmacy, Universitas Padjadjaran, for providing the support and their facilities, and also to Rifa Nurfauziah, Bella Puteri Irinda, Anggia Diani Amaliah for the technical support.

\section{FUNDING}

This research was funded by Universitas Padjadjaran Internal Grant RFU 2017/2018.

\section{AUTHORS CONTRIBUTIONS}

All the authors have contributed equally.

\section{CONFLICTS OF INTERESTS}

Declared none

\section{REFERENCES}

1. Alzohairy MA. Therapeutics role of Azadirachta indica (Neem) and their active constituents in diseases prevention and treatment. Evid Based Complement Alternat Med 2016;2016:1-11.

2. Liauw MY, Natan F, Widiyanti P, Ikasari D, Indraswati N, Soetaredjo F. Extraction of neem oil (Azadirachta indica A. Juss) using n-hexane and ethanol: studies of oil quality, kinetic and thermodynamic. ARPN J Eng Appl Sci 2008;3:49-54.

3. Ayoola A, Efeovbokhan VE, Bafuwa O, David O. A search for an alternative solvent to hexane during neem oil extraction. Int J Sci Tech 2014;4:66-70.

4. Johnson S, Morgan ED. Supercritical fluid extraction of oil and triterpenoids from neem seeds. Phytochem Anal 1997;8:228-32.

5. Abdel Ghaffar F, Al Quraishy S, Al Rasheid KA, Mehlhorn H. Efficacy of a single treatment of head lice with a neem seed extract: an in vivo and in vitro study on nits and motile stages. Parasitol Res 2012;110:277-80. 
6. Putriana NA, Hakim A, Husni $\mathrm{P}$, Rusdiana $\mathrm{T}$. In vitro effectiveness of neem oil (Azadirachta Indica A. Juss) shampoo as anti head lice (Pediculus humanus capitis). Pharm Clin Pharm Res 2019;4:76-80.

7. Thomas C, Coates SI, Engelman D, Chosidow O, Chang AY. Ectoparasites: scabies. J Am Acad Dermatol 2020;82:533-48.

8. Leung AKC, Lam JM, Leong KF. Scabies: a neglected global disease. Curr Pediatr Rev 2020;16:33-42.

9. WHO. Scabies. 2020. Available from: https://www.who.int/ news-room/fact-sheets/detail/scabies. [Last accessed on 25 Feb 2020].

10. Parman P, Hamdani H, Rachman I, Pratama A. Personal hygiene risk factors for students against the incidence of scabies skin disease in Al-Baqiyatushshalihat Islamic Boarding School, Tanjung Jabung Barat in 2017 (Faktor risiko hygiene perorangan santri terhadap kejadian penyakit kulit skabies di Pesantren Al-baqiyatushshalihat Tanjung Jabung Barat tahun 2017). J Ilm Univ Batanghari Jambi 2017;17:243-52.

11. Dressler C, Rosumeck S, Sunderkotter C, Werner RN, Nast A. The treatment of scabies. Dtsch Arztebl Int 2016;113:757-62.

12. Mayba JN, Gooderham MJ. A guide to topical vehicle formulations. J Cutan Med Surg 2018;22:207-12.

13. Bolla PK, Clark BA, Juluri A, Cheruvu HS, Renukuntla J. Evaluation of formulation parameters on permeation of ibuprofen from topical formulations using strat-M((R)) membrane. Pharmaceutics 2020;12:151.

14. Putriana N, Husni P. Effectiveness test of neem oil cream (Azadirachta indica A. Juss) as antiscabies in New Zealand rabbits in the international seminar on pharmaceutical science and technology. Indonesia: J Pharm Sci Res 2018;1:170-9.

15. Bott RF, Oliveira WP. Storage conditions for stability testing of pharmaceuticals in hot and humid regions. Drug Dev Ind Pharm 2007;33:393-401.

16. Bajaj S, Singla D, Sakhuja N. Stability testing of pharmaceutical products. J Appl Pharm Sci 2012;2:129-38.

17. Husni P, Amalia AD, Mita SR, Putriana NAJI. Formulation and physical evaluation of cream containing neem oil $5 \%$. Indonesian J Pharm 2019;1:72-6.

18. Hamadou B, Djomdi, Falama RZ, Delattre C, Pierre G, Dubessay $\mathrm{P}$, et al. Influence of physicochemical characteristics of neem seeds (Azadirachta indica A. Juss) on biodiesel production. Biomolecules 202;10:616-25.

19. Das P, Sharma N, Puzari A, Kakati DK, Devi N. Synthesis and characterization of neem (Azadirachta indica) seed oil-based alkyd resins for efficient anticorrosive coating application. Polym Bull 2021;78:457-79.

20. Ardhany SD, Putra CD, Novaryatiin S. Modification of anti-acne bawang dayak (Eleutherine bulbosa (Mill.)Urb.) cream to propionibacterium acnes. J Adv Pharm Technol Res 2021;12:94-8.

21. Ali A, Akhtar A, Khan HMS. Assessment of physical stability and antioxidant activity of polysiloxane polyalkyl polyether copolymer-based creams. J Chem 2013;2013:1-7.

22. Mardhiani YD, Azhari DP, Wulansari SJI. Influence of emollient on the preparation and stability of sodium ascorbyl phospate cream. Indones J Pharm 2019;1:33-9.

23. International Conference on Harmonization. Q2 Validation of analytical procedures: text and methodology international conference on harmonization of technical requirements for registration of pharmaceutical for human use, ICH Harmonized Tripartite Guideline; 2005. Available from: https://www.gmpcompliance.org/files/guidemgr/Q2(R1).pdf. [Last accessed on 12 Mar 2021].

24. Lambers H, Piessens S, Bloem A, Pronk H, Finkel P. Natural skin surface $\mathrm{pH}$ is on average below 5 , which is beneficial for its resident flora. Int J Cosmet Sci 2006;28:359-70.

25. Proksch E. pH in nature, humans and skin. J Dermatol 2018;45:1044-52.

26. Sopyan I, Gozali D, Tiassetiana S. Formulation of tomato extracts (Solanum lycopersicum L.) as a sunscreen lotion. Natl J Physiol Pharm Pharmacol 2018;8:453-8.

27. Goodarzi F, Zendehboudi S. A comprehensive review on emulsions and emulsion stability in chemical and energy Industries. Can J Chem Eng 2019;97:281-309.

28. Saputri FA, Muchtaridi M. Analytical method development and validation for the determination of caffeine in green coffee beans (Coffea arabica L.) from three districts of West Java, Indonesia by high-performance liquid chromatography. Int J Appl Pharm 2018;10:107-11.

29. PubChem. PubChem compound summary for CID 5281303, Azadirachtin; 2021. Available from: https://pubchem.ncbi.nlm.nih.gov/compound/Azadirachtin. [Last accessed on 26 Feb 2021].

30. Bhuyian MHU, Rasyid DH, Mohsin M, Tahera K. An overview: stability study of pharmaceutical product and shelf-life prediction. Eur Biomed Sci 2015;2:30-40.

31. Iskandarsyah, Harmita, Azzahra AR. Accelerated stability testing of anti-aging cream: formation of myristic acid and stearic acid as degradation products. Int J Appl Pharm 2018;10:1-5. 